\title{
Alternative Hosts in the Families Poaceae and Cyperaceae for Xanthomonas vasicola pv. vasculorum, Causal Agent of Bacterial Leaf Streak of Corn
}

\author{
T. Hartman, ${ }^{1,2}$ B. Tharnish, ${ }^{1}$ J. Harbour, ${ }^{1,3}$ G. Y. Yuen, ${ }^{1}$ and T. A. Jackson-Ziems ${ }^{1, \dagger}$
}

${ }^{1}$ Department of Plant Pathology, University of Nebraska-Lincoln, Lincoln, NE 68583

2 Bayer CropScience, Sabin, MN 56580

3 JTK Agriculture, LLC, Lincoln, NE 68504

Accepted for publication 20 January 2020.

\begin{abstract}
The bacterial pathogen Xanthomonas vasicola pv. vasculorum was first reported in the United States causing bacterial leaf streak on Nebraska corn (Zea mays) in 2016. The bacterium is also known to cause disease in sugarcane, grain sorghum, broom bamboo, and various palm species. The objective of this study was to identify alternative hosts for $X$. vasicola pv. vasculorum among plants commonly found in corn growing areas of the United States. In repeated greenhouse experiments, 53 species of plants found in the United States that had not been tested previously for susceptibility to $X$. vasicola pv. vasculorum were inoculated with the pathogen and monitored for symptom development. Eleven species in the family Poaceae exhibited symptoms: oat (Avena sativa), rice (Oryza sativa), orchardgrass (Dactylis glomerata), indiangrass (Sorghastrum nutans), big bluestem (Andropogon gerardii), little bluestem (Schizachyrium scoparium), timothy (Phleum pratense), sand bluestem (Andropogon
\end{abstract}

ABSTRACT

Bacterial leaf streak, caused by the bacterium Xanthomonas vasicola pv. vasculorum is one of the most recently reported diseases to threaten production of corn (Zea mays), or maize, in the United States. Prior to the 2016 report in the United States, the disease had only been reported on corn in South Africa (Dyer 1949). The disease has since been confirmed in corn in eight other states: Colorado, Illinois, Iowa, Kansas, Minnesota, South Dakota, Oklahoma, and Texas (Bowman and Bissonnette 2016; Damicone et al. 2018; Lang et al. 2017; Robertson 2016). Recently, X. vasicola pv. vasculorum has also been reported on corn in Argentina (Plazas et al. 2018) and Brazil (Leite et al. 2018).

Bacterial leaf streak foliar symptoms on corn include watersoaked, yellow to brown interveinal streaks on the leaves (Supplementary Figs. S1 and S2), which are typically first observed in the lower canopy (Korus et al. 2017). X. vasicola pv. vasculorum is also known to infect sugarcane (Saccharum spp.), causing gumming disease, a leaf blight and vascular wilt, in various regions around the world but not in the United States (North 1935). According to Ricaud and Autrey (1989), the bacterium also causes leaf blighting of multiple palm species (Dictyosperma album, Roystonea regia, and Areca catechu) and broom bamboo (Thysanolaena maxima). Korus et al. (2017) and Lang et al. (2017) demonstrated that $X$. vasicola pv. vasculorum can

${ }^{\dagger}$ Corresponding author: T. A. Jackson-Ziems; tjackson3@unl.edu

Funding: Support was provided by the Nebraska Corn Board.

*The $\boldsymbol{e}$-Xtra logo stands for "electronic extra" and indicates that two supplementary figures are published online.

The author(s) declare no conflict of interest.

(C) 2020 The American Phytopathological Society hallii), green foxtail (Setaria viridis), bristly foxtail (Setaria verticillata), and johnsongrass (Sorghum halepense). Yellow nutsedge (Cyperus esculentus) in the Cyperaceae also was a symptomatic host. In addition, endophytic colonization by $X$. vasicola pv. vasculorum was found in three asymptomatic alternative hosts: downy brome (Bromus tectorum), tall fescue (Festuca arundinacea), and western wheatgrass (Pascopyum smithii). Experiments were also conducted in the field to determine the potential for alternative hosts to become infected by natural inoculum. Symptoms developed only in big bluestem and bristly foxtail in field experiments. These results suggest that infection of alternative hosts by $X$. vasicola pv. vasculorum can occur, but infection rates might be limited by environmental conditions.

Keywords: bacteriology, ecology and epidemiology infect grain sorghum (Sorghum bicolor), although this has not been observed in the field.

Because bacterial leaf streak was only recently reported in corn in the United States, management strategies such as host resistance have not been established. The pathogen is presumed to overwinter in corn debris, and therefore, removal of infested debris and crop rotation are potential management options. The efficacy of these cultural practices, however, may be dependent upon whether or not the bacterium can infect and survive in other plants that grow in corn production areas. Several pasture grasses, weeds, turfgrasses, ornamental plants, and crop species can be found growing in or near corn production fields in the United States (Stubbendieck et al. 1994; Weaver and Bruner 1948). But, other than the demonstration that $X$. vasicola pv. vasculorum can infect grain sorghum (Korus et al. 2017; Lang et al. 2017), the potential of such plants to be alternative hosts of $X$. vasicola pv. vasculorum has not been investigated. Addressing this question was the primary objective of this study. In previous host range studies on $X$. vasicola pv. vasculorum, only plants displaying symptoms following inoculation with the pathogen or exhibiting symptoms in field settings were considered to be hosts. The related bacterium, X. campestris, was found in asymptomatic plants such as citrus, clover and sugarcane (Araujo et al. 2002; Burch and Sarathchandra 2006; Velázquez et al. 2008). This raises the possibility that $X$. vasicola pv. vasculorum might also be able to colonize plants endophytically without eliciting symptom development, in which case endophytic colonization, along with symptom development, must be used as criteria in determining the host range for this pathogen. Thus, an experiment in this study was designed to evaluate the potential for several plant species to be symptomatic or asymptomatic alternative hosts of $X$. vasicola pv. vasculorum. In a separate experiment, the susceptibility of some symptomatic alternative hosts to infection by the pathogen was investigated under field conditions. The research described here is part of an M.S. thesis (Hartman 2018) and portions 
of these results have been previously presented (Hartman et al. 2017a, b, 2018).

\section{MATERIALS AND METHODS}

Greenhouse host range experiment design. Fifty-three plant species that had not been evaluated previously as hosts for $X$. vasicola pv. vasculorum were tested for susceptibility to the pathogen under controlled conditions (Table 1). All of the species, except for Oryza sativa (rice), can be commonly found in or near Nebraska cornfields. Cultivated species included cereal crops, pasture/cover crop grasses, and turf and landscape plants. In addition, 14 dicot and monocot weeds commonly found in the United States were tested. Susceptible corn hybrid DKC 61-88 was included as a positive control to confirm that the pathogen inoculum was virulent and environmental conditions were conducive to disease development. Grain sorghum cultivar TX430 was included as a positive control alternative host to confirm that the strain was sufficiently virulent to cause disease on a host other than corn. A wild (shattercane) population of Sorghum bicolor also was included in the experiments to determine whether the wild population can be as susceptible as grain sorghum. One cultivar or population for each species was tested, except for Sorghum bicolor. Each plant species was sown separately into steam pasteurized soil contained in $15 \mathrm{~cm}$ diameter clay pots; numbers of seed and planting depth varied by seed size (Dawson and Bruns 1962; Newman and Moser 1907). After emergence, plants were thinned to fewer than five per pot. The plants were grown in a greenhouse with daily watering and insect pest control as needed. To avoid pathogen dispersal via plant to plant contact, pots were spaced at least $13 \mathrm{~cm}$ apart. Plants were inoculated with the pathogen when at least $50 \%$ of the plants of each species had four fully expanded leaves.

The experiment was performed twice, with the two trials conducted in separate greenhouses located at the University of Nebraska-Lincoln. Average temperatures in the greenhouses were $28^{\circ} \mathrm{C}$ during the day and $22^{\circ} \mathrm{C}$ at night, and average relative humidity was $40 \%$. There was $16 \mathrm{~h}$ of light and $8 \mathrm{~h}$ of darkness.

Greenhouse inoculations. Strain $201600401 X$ of $X$. vasicola pv. vasculorum, used to inoculate all plants, was isolated in 2016 from a diseased corn leaf obtained from Clay County, NE and stored at $-80^{\circ} \mathrm{C}$ in a proprietary storage solution (Microbank; Pro-Lab Diagnostics Inc., Toronto, Canada). The strain's identity was determined previously to be $X$. vasicola $\mathrm{pv}$. vasculorum via a PCR assay (Lang et al. 2017), and its virulence was confirmed on corn hybrid DKC 61-88 (Korus et al. 2017). To produce inoculum, the strain was revived from storage by streaking onto nutrient broth yeast extract (NBY) agar (Vidaver 1967) to obtain single colonies, which then were streaked onto fresh NBY agar plates. After the plates were incubated at $27^{\circ} \mathrm{C}$ for $72 \mathrm{~h}$, the amount of time required for the cultures to completely cover the agar surface, the cells were scraped off the plates with a sterile plastic scraper, and suspended in sterile water $(250 \mathrm{ml}$ of water per plate). Plating of serial dilutions of the cell suspensions confirmed that they contained approximately $10^{8}$ colony forming units (CFU) of $X$. vasicola pv. vasculorum per ml.

There were five experimental units (pots) for each plant species in each trial of the experiment. To accommodate the large number of treatments (plant species), one pot of each plant species, containing three to five plants, was inoculated with the pathogen in each of five inoculation times separated by roughly $12 \mathrm{~h}$ intervals. A fresh bacterial cell suspension was prepared for each inoculation time. Plants were sprayed with the suspension until runoff, which deposited roughly $10 \mathrm{ml}$ of inoculum per pot. Inoculated plants were placed in a humidity chamber at $100 \%$ humidity for $12 \mathrm{~h}$ and then transferred to a greenhouse. The top inoculated leaf on each plant was marked to allow observation of possible systemic movement of the bacteria from inoculated leaves to noninoculated leaves.
Negative controls of each plant species were mock inoculated with sterile water and maintained under similar conditions in a separate greenhouse to prevent accidental inoculation with the pathogen. Plants were monitored for symptoms every $48 \mathrm{~h}$ for up to 21 days postinoculation.

Assessment of plants for symptoms and pathogen presence. When putative bacterial leaf streak symptoms were observed on an inoculated plant, a $3 \mathrm{~cm}$ by $3 \mathrm{~cm}$ piece of symptomatic leaf was excised and examined for bacterial streaming at $200 \times$ magnification to verify that the symptoms were associated with a bacterium (Korus et al. 2017). If bacterial streaming was observed, symptom severity on the infected plant was visually estimated 21 days postinoculation as the proportion, in $1 \%$ increments, of the inoculated leaf area on each plant covered by lesions. Three symptomatic leaves were also collected from each pot for pathogen isolation. Pieces of symptomatic tissue $\left(9 \mathrm{~cm}^{2}\right)$ collected from a pot were surface disinfested in a 50:50 mixture of 70\% ethanol and 10\% sodium hypochlorite (Schulz et al. 1993) for $30 \mathrm{~s}$, and washed three times for $30 \mathrm{~s}$ with sterile water to remove the disinfectant. The efficacy of the surface disinfestation procedure was verified with the imprint method (Schulz et al. 1993). The disinfested leaf tissue was placed in $200 \mu \mathrm{l}$ of sterile water in a $500 \mu \mathrm{l}$ microcentrifuge tube, and cut five times with flame-sterilized scissors to allow bacteria to flow out of the tissue into the water. One hour later, a sterile inoculation loop was used to streak fluid onto an NBY plate. Plates were observed for growth of $X$. vasicola pv. vasculorum every $24 \mathrm{~h}$ for up to 5 days.

The identity of bacterial colonies suspected to be $X$. vasicola $\mathrm{pv}$. vasculorum was confirmed with a PCR assay developed by Lang et al. (2017). Colonies were picked from isolation plates with sterile toothpicks and suspended in $100 \mu \mathrm{l}$ of DNAse and protease-free water that was previously filtered through a 0.2 micron filter and autoclaved (Fisher Bioreagents, Waltham, MA). The bacterial suspensions were used as templates in PCR amplifications with primers 5'CAAGCAGAGCATGGCAAAC3' and 5'CACGTA GAACCGGTCTTTGG3' (Integrated DNA Technologies, Coralville, IA). Commercially-prepared DreamTaq $2 \times$ PCR Master Mix (Thermo Scientific, Waltham, MA) was substituted for the reaction buffer, dNTP, and GoTaq DNA polymerase mixture reported in Lang et al. (2017).

Plants that did not exhibit bacterial leaf streak symptoms 21 days postinoculation were analyzed for populations of $X$. vasicola pv. vasculorum within leaf tissues. Five inoculated leaves were collected from each pot, dried for 3 days at $27^{\circ} \mathrm{C}$ in a drying oven to standardize moisture content, and then weighed. Leaves were surface disinfested as described above, and then placed in $300 \mu \mathrm{l}$ of sterile water in $500 \mu \mathrm{l}$ microcentrifuge tubes and cut with flamesterilized scissors to allow bacteria to flow out of the leaf tissue. After $1 \mathrm{~h}$, the extract was serially diluted and $100 \mu \mathrm{l}$ of each dilution was spread onto five replicate NBY plates. Plates were incubated at $27^{\circ} \mathrm{C}$ for 5 days when suspected colonies of $X$. vasicola pv. vasculorum were counted. Representative colonies were verified to be $X$. vasicola pv. vasculorum with the PCR procedure described above. The population density of $X$. vasicola pv. vasculorum measured in each leaf sample tissue was expressed as $\log _{10} \mathrm{CFU}$ per g (dry weight) of leaf tissue.

Field study. Eight plant species identified during previous greenhouse experiments to be symptomatic hosts for $X$. vasicola pv. vasculorum - big bluestem (Andropogon gerardii 'Champ'), bristly foxtail (Setaria verticillata), green foxtail (Setaria viridis), indiangrass (Sorghastrum nutans 'Holt'), little bluestem (Schizachyrium scoparium 'Blaze'), oat (Avena sativa 'Jerry'), orchardgrass (Dactylis glomerata 'Latar'), and timothy (Phleum pratense 'Climax') were used in a field study to determine the likelihood of infection by the pathogen in a natural corn production setting. Five other species found in the greenhouse experiments to be symptomatic hosts were not examined in the field due to concerns about the unintentional introduction of these potentially invasive species into noninfested 
fields. The study consisted of simultaneous experiments conducted in two different locations at the University of Nebraska South Central Agricultural Laboratory, Clay Center, NE during the 2017 growing season. In each experiment, an individual plant was an experimental unit and there were 15 replicate plants for each plant species. Individual plants were grown initially in $8 \mathrm{~cm}$ plastic pots containing pasteurized soil in a greenhouse at the University of Nebraska-Lincoln under the growing conditions described above. When plants reached the two-leaf stage, they were acclimated to outdoor conditions by placement outside the greenhouse for $2 \mathrm{~h}$ every morning for 3 days, then $5 \mathrm{~h}$ from the

TABLE 1. Results of greenhouse host range testing of Xanthomonas vasicola pv. vasculorum ${ }^{\mathrm{z}}$

Plant category; response to inoculation

Plant species, common name, cultivar (if known)

Annual cereal crop plants

Symptomatic hosts

Avena sativa, oat, 'Jerry'

Oryza sativa, rice, 'Jupiter'

Sorghum bicolor, grain sorghum, 'TX430'*

Asymptomatic hosts

Zea mays, corn, hybrid DKC 61-88*

None

Nonhosts

Hordeum vulgare, barley, NB14430

Panicum virgatum, switchgrass

Secale cereal, cereal rye, 'Elbon'

Setaria italic, foxtail millet

Triticum aestivum L., wheat, 'Settler CL'

Triticosecale, triticale, 'NT13416'

Perennial pasture, turf and landscape plants

Symptomatic hosts

Andropogon gerardii, big bluestem, 'Champ'

Sorghastrum nutans, indiangrass, 'Holt'

Schizachyrium scoparium, little bluestem, 'Blaze'

Dactylis glomerate, orchardgrass, 'Latar'

Andropogon hallii, sand bluestem

Phleum pretense, Timothy, 'Climax'

Asymptomatic hosts

Nonhosts

Pascopyrum smithii, western wheatgrass

Lolium multiflorum, annual ryegrass, 'Gulf'

Bouteloua gracilis, bluegrama, 'Bad River'

Agrostis stolonifera, creeping bentgrass

Alopecurus arundinaceus, creeping foxtail, 'Garrison'

Agropyron cristatum, crested wheatgrass

Festulolium loliaceum, festulolium

Nassella viridula, green needle

Koeleria macrantha, junegrass

Bromus riparius, meadow brome, 'Fleet'

Calamovilfa longifolia, prairie sandreed, 'Goshen'

Thinopyrum intermedium, pubescent wheatgrass, 'Manska'

Phalaris arundinacea, reed canary

Sporobolus cryptandrus, sand dropseed, 'VNS'

Bouteloua curtipendula, sideoats grama, 'Butte'

Elymus trachycaulus, slender wheatgrass

Thinopyrum ponticum, tall wheatgrass

Elymus lanceolatus, thickspike wheatgrass

Elymus virginicus, Virginia wild rye

Turf and ornamental plants

Symptomatic hosts

Asymptomatic hosts

Nonhosts

Weeds

Symptomatic hosts

Asymptomatic hosts

Nonhosts
None

Festuca arundinacea, tall fescue, 'Cajun II'

Cynodon dactylon, Bermudagrass

Buchloe dactyloides, buffalograss

Hemerocallis sp., daylily

Poa pratensis, Kentucky bluegrass

Pennisetum glaucum, ornamental pearl millet

Lolium perenne, perennial ryegrass

Zoysia matrella, zoysiagrass

Cyperus esculentus, yellow nutsedge

Setaria verticillata, bristly foxtail

Setaria viridis, green foxtail

Sorghum halepense, Johnsongrass

Sorghum bicolor, shattercane*

Bromus tectorum, downy brome

Amaranthus palmeri, Palmer amaranth

Bromus inermis, smooth brome, 'VNS'

Cenchrus longispinus, sandbur

Digitaria sanguinalis, large crabgrass

Echinochloa crus-galli, barnyardgrass

Panicum dichotomilflorum, fall panicum

Setaria faberi, giant foxtail

Setaria pumila, yellow foxtail

$\mathrm{z} *$ Zea mays and Sorghum bicolor were previously reported to be hosts and were included as positive susceptible controls. Grain sorghum and shattercane (weed) populations were used to represent Sorghum bicolor. Plants tested in the greenhouse for susceptibility to infection by X. vasicola pv. vasculorum listed according to their primary usage and response to pathogen inoculation: symptomatic host $=$ symptoms developed and pathogen detected in tissues; asymptomatic host $=$ no symptoms but pathogen detected in tissues; and nonhost = no symptoms, no pathogen detection. 
morning into early afternoon daily for 3 days, and then $8 \mathrm{~h}$ daily for 5 days. After acclimation, the plants were transplanted into the field experiments.

Each experiment had a completely randomized design in which fifteen replicate plants of each species were transplanted between corn rows within a no-till area $(6 \mathrm{~m} \times 6 \mathrm{~m})$, continuous corn field known to be infested with $X$. vasicola pv. vasculorum. Experimental units were randomly assigned a position in the field with a random number generator, where each number corresponded to a position in the field. The transplantation occurred on 28 June 2017, when the corn was at the ninth vegetative growth stage. To reduce stress on the transplants, the field was irrigated with overhead irrigation the same day following transplantation. Test plants were asymptomatic at the time of transplanting. While the experiment areas were not inoculated, bacterial leaf streak symptoms were evident in the surrounding corn plants at approximately $30 \%$ severity and near $100 \%$ incidence.

All plants were examined for symptoms at 2-week intervals until they began to senesce approximately 12 weeks after transplantation. Microscopic examination of symptomatic leaf tissue for bacterial streaming, isolation of the bacterial pathogen, confirmation of $X$. vasicola pv. vasculorum, and disease severity ratings estimated in $1 \%$ increments were conducted with the same methods as used in the greenhouse experiment described above. Concurrent to the field experiments, plants of each species were maintained in the greenhouse as negative controls to confirm that infection observed in the field did not result from infection before transplanting while plants were grown in the greenhouse or during acclimation.

Statistical analyses. Disease severity and pathogen population density data from the greenhouse host range experiment were subjected to analysis of variance (ANOVA) in R version 3.4.0, a two-way analysis of variance was applied, with experiment trials and plant species being the factors and inoculation times being treated as blocks. Only data for those plant species in which bacterial leaf streak symptoms developed and in which the pathogen was recovered were used in the statistical analyses. A similar twoway ANOVA was performed for disease severity data from the field experiment, with data from plant species that developed bacterial leaf streak symptoms being included in the analysis. Tukey's honestly significant difference test was used for means separation $(\alpha=0.05)$ in all data sets.

\section{RESULTS}

Greenhouse host range experiment. Among the 53 plant species that had not been tested previously for susceptibility to

TABLE 2. Disease development in the greenhouse in plants inoculated with Xanthomonas vasicola pv. vasculorum 21 days after inoculation ${ }^{\mathrm{z}}$

\begin{tabular}{lcc}
\hline Species & $\begin{array}{c}\text { Severity (\% leaf area } \\
\text { covered by lesions) }\end{array}$ & $\begin{array}{c}\text { Incidence } \\
\text { (\% of plants infected) }\end{array}$ \\
\hline Big bluestem & $14 \mathrm{de}$ & 100 \\
Bristly foxtail & $7 \mathrm{~b}$ & 100 \\
Corn & $29 \mathrm{f}$ & 100 \\
Grain sorghum & $8 \mathrm{bc}$ & 100 \\
Green foxtail & $8 \mathrm{bc}$ & 100 \\
Indiangrass & $12 \mathrm{~cd}$ & 100 \\
Little bluestem & $12 \mathrm{~cd}$ & 100 \\
Oat & $16 \mathrm{de}$ & 100 \\
Orchardgrass & $5 \mathrm{ab}$ & 100 \\
Rice & $7 \mathrm{~b}$ & 100 \\
Sand bluestem & $4 \mathrm{ab}$ & 50 \\
Timothy & $2 \mathrm{a}$ & 80 \\
Shattercane & $5 \mathrm{ab}$ & 100 \\
Johnsongrass & $18 \mathrm{e}$ & 100 \\
Yellow nutsedge & $2 \mathrm{a}$ & 100 \\
\hline
\end{tabular}

$\mathrm{z}$ Values with the same letters are not significantly different $(\alpha=0.05)$ according to Tukey's honestly significant difference test. Results are means from two trials, each with 15 replications.
$X$. vasicola pv. vasculorum, 12 displayed symptoms on inoculated leaves typical of infection by the pathogen (Table 1). These symptoms included yellow to brown lesions with wavy or straight margins between the leaf veins. All positive control corn plants inoculated with the bacterium also displayed these symptoms. Inoculated leaves of johnsongrass (Sorghum halepense), shattercane, and the grain sorghum positive control displayed similar streaking red to purple in color. Observation of bacterial streaming from infected leaves and identification of isolated bacteria as $X$. vasicola pv. vasculorum via the pathogen-specific PCR assay confirmed that these symptoms were caused by $X$. vasicola $\mathrm{pv}$. vasculorum. Additionally, symptoms were not observed on and the pathogen was not detected in leaves that were not present at the time of inoculation of symptomatic hosts. Water-inoculated negative controls of all symptomatic host species showed no symptoms, and the pathogen was not recovered from or detected in the leaves of these plants.

Susceptibility to $X$. vasicola pv. vasculorum differed among the symptomatic hosts. There was a significant $(P<0.0001)$ plant species effect for disease severity measured as percent diseased leaf area over the two trials of the experiment. Among the test species exhibiting symptoms, severity was least on timothy, shattercane, and yellow nutsedge (Cyperus esculentus), at 2\% severity, and most severe on johnsongrass and oat, at $18 \%$ (Table 2). Disease severity on the positive control corn (29\%) was significantly higher than on all other species. Over the two trials of the experiment, disease incidence was $100 \%$ for every symptomatic host species except for sand bluestem (50\%) and timothy (80\%) (Table 2).

Downy brome (Bromus tectorum), tall fescue (Festuca arundinacea), and western wheatgrass (Pascopyrum smithii) were found to be asymptomatic hosts for $X$. vasicola pv. vasculorum. Despite the absence of symptoms on any inoculated leaves, the pathogen was detected by isolation from $60 \%$ of western wheatgrass and downy brome plants, and $30 \%$ of tall fescue plants (data not shown). The pathogen was isolated only from the lower leaves of the plants that were inoculated and was not detected in leaves of mockinoculated controls of these species. Mean population densities of $X$. vasicola pv. vasculorum measured in leaf tissues were similar among these three asymptomatic host species (5.1 log to $5.8 \mathrm{log}$ CFU/g of leaf tissue) (Fig. 1). In contrast, the mean population density of $X$. vasicola pv. vasculorum detected in corn exceeded 9 $\log \mathrm{CFU} / \mathrm{g}$.

Infection of alternative hosts in the field. Following transplantation of eight plant species into corn fields infested with $X$. vasicola pv. vasculorum, bacterial leaf streak symptoms developed in big bluestem and bristly foxtail. A low incidence of disease occurred over the two field trials in both species, with fewer than $18 \%$ of the plants developing disease symptoms. In the ANOVA for disease severity, the 'trial' factor was insignificant. Average disease severity among infected plants of big bluestem and bristly foxtail were 5 and $15 \%$, respectively (Table 3 ). X. vasicola pv. vasculorum was isolated from symptomatic plants but not from any asymptomatic plants transplanted into the field. Plants maintained as negative controls in the greenhouse did not develop symptoms, and the bacterium was not detected in any of these plants.

\section{DISCUSSION}

The greenhouse host range experiment revealed 15 new plant species to be symptomatic or asymptomatic hosts for $X$. vasicola $\mathrm{pv}$. vasculorum. The bacterium was pathogenic, i.e., caused disease symptoms, on 12 of the species. Nearly all these species are members of the Poaceae. The exception was yellow nutsedge, which is in the Cyperaceae. These results considerably expand the known host range of $X$. vasicola pv. vasculorum beyond corn, grain sorghum, sugarcane and broom bamboo in the Poaceae and palm 
species in the Arecaceae (Ricaud and Autrey 1989), and support $X$. vasicola pv. vasculorum having an extensive host range among monocots. The symptoms on these species, as well as on Sorghum bicolor previously known to be a host, were not as severe as symptoms observed on the positive control corn hybrid. These results are consistent with research by Lang et al. (2017), which indicated that the pathogen isolated from corn was more virulent on corn than on sorghum or sugarcane. Thus, while the strain of $X$. vasicola pv. vasculorum used in this study may be pathogenic on other hosts, it is possible that it is better adapted to infecting corn. Interestingly, symptoms on johnsongrass in this experiment were more severe than on closely related grain sorghum or shattercane, demonstrating the need to examine the susceptibility of closely related plants. Additionally, disease severity on grain sorghum did not differ from disease severity on shattercane. This indicates that wild and domestic populations of Sorghum bicolor do not differ in their susceptibility to $X$. vasicola $\mathrm{pv}$. vasculorum. The identification of three other plant species in the Poaceae being asymptomatic hosts for $X$. vasicola pv. vasculorum was based on the pathogen being detected within the leaves of inoculated plants. Although pathogen population densities in the asymptomatic hosts were much lower compared with that in symptomatic corn, population densities approaching $10^{6} \mathrm{CFU} / \mathrm{g}$ of tissue did result from spray inoculation, raising the possibility that $X$. vasicola pv. vasculorum might be able to naturally infect these asymptomatic hosts and establish endophytic populations in the field. According to Vidaver and Lambrecht (2004), pathogen populations of at least $10^{6} \mathrm{CFU}$ are associated with disease development. Given that populations of $X$. vasicola pv. vasculorum in asymptomatic hosts did not exceed $10^{6} \mathrm{CFU}$, populations may have been too low to elicit symptoms in these hosts. Only one cultivar or population of each of these asymptomatic hosts was tested in the greenhouse experiment and so the possibility remains that $X$. vasicola pv. vasculorum could multiply more aggressively and cause disease symptoms in other populations of these plant species.

The field experiment provided evidence that alternative hosts of $X$. vasicola pv. vasculorum can become infected by natural pathogen inoculum under natural environmental conditions. Only two of the eight plant species that were susceptible in the greenhouse became infected when transplanted into the field, however, and the incidence and severity of disease among these plants in the field was much lower than in the greenhouse. The most likely explanation for the low infection rates is that environmental conditions occurring during the field experiment were not very conducive to infection by the pathogen. This supposition is supported by the observation that during the 2017 growing season when the experiment was conducted, overall incidence and severity of bacterial leaf streak in Nebraska corn fields were less than that observed during the 2016 and 2018 growing seasons (T. JacksonZiems, unpublished data). It can be presumed that environmental conditions favorable to metabolism and multiplication of the pathogen was provided in the greenhouse experiments, but it is also possible that conditions in the greenhouse predisposed the host plants to infection by the pathogen. These predisposing conditions may not have occurred or may have had less effects on the host plants in the field. However, the specific environmental factors that govern the ability of $X$. vasicola pv. vasculorum to disperse and infect and that affect the response of the hosts to infection by the bacterium are unknown. Another explanation for the low incidence of natural infection in the field experiments may be the indigenous pathogen strains in the field experiment are less virulent on the alternative hosts than the strain used in the greenhouse experiments. But, while differences in host range were reported among $X$. vasicola pv. vasculorum strains isolated from widely separated geographic areas, host range diversity among strains from different locations in Nebraska or within the northern Great Plains region has not been assessed.

Until there is better understanding of how environmental factors and pathogen strain diversity affects disease development, validation of results from greenhouse experiments with field studies is essential. The field experiments were conducted in two locations which might not have represented the full range of field environments under which bacterial leaf streak might develop. Therefore, the six new host species that were not infected when transplanted to the field ought to be evaluated further across a broader range of locations. In addition, there are symptomatic and asymptomatic host species identified in the greenhouse experiment which were not evaluated for susceptibility in field. Research with these alternative host species also needs to be conducted in multiple field environments to better establish the potential for infection of these alternative host species under natural conditions.

The importance of endophytic colonization by the pathogen in asymptomatic hosts, in particular, needs to be examined in light of the endophytic populations surviving through the winter in the overwintering tissues and above-ground debris of the alternative hosts and the endophytic populations in asymptomatic host tissue serving as inoculum for infection of corn. There is also a need to compare different cultivars or varieties of the alternative host species for susceptibility to infection by $X$. vasicola $\mathrm{pv}$. vasculorum and the capacity to sustain endophytic colonization by the pathogen. As an example of how this information could be important, the variety of tall fescue shown in this study to be an asymptomatic host is commonly planted in pastures for forage, but is not used in landscape turf. Varieties of tall fescue selected for use in turf need to be examined for their potential to become symptomatically infected by the pathogen or to harbor the pathogen in order to determine the potential for landscape plantings in proximity to agricultural corn fields sustaining damage from inoculum originating from corn or

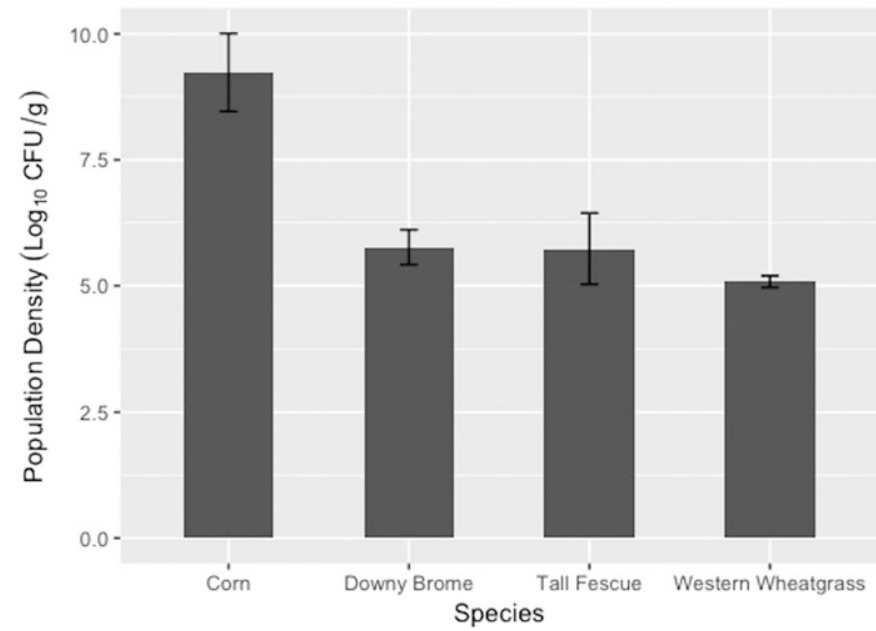

Fig. 1. Population densities of Xanthomonas vasicola pv. vasculorum detected in leaf tissues 21 days after spray inoculation of leaves with a $10^{8} \mathrm{CFU} / \mathrm{ml}$ aqueous suspension of $X$. vasicola pv. vasculorum. Results are means of two trials with five replications per trial. Leaves with no detectable pathogen population were not included in the calculations of mean populations. Error bars denote standard error of the mean.

TABLE 3. Disease incidence and severity on alternative host plants transplanted into fields of corn with bacterial leaf streak caused by Xanthomonas vasicola pv. vasculorum ${ }^{\mathrm{z}}$

\begin{tabular}{|c|c|c|}
\hline Species & $\begin{array}{c}\text { Average severity } \\
\text { (\% leaf area covered by lesions) }\end{array}$ & $\begin{array}{c}\text { Incidence } \\
\text { (\% plants infected })\end{array}$ \\
\hline Bristly foxtail & $5 \mathrm{a}$ & 17 \\
\hline Big bluestem & $15 \mathrm{~b}$ & 8 \\
\hline
\end{tabular}

$\mathrm{z}$ Values with the same letters are not significantly different $(\alpha=0.05)$ according to analysis of variance. Results are means from two trials, each with 15 replicate plants. Only species displaying symptoms were included. 
serving as sites of pathogen survival and sources of inoculum for infection of corn crops.

While an extensive list of plant species was tested in this study, further research is needed to determine if the pathogen is capable of infecting other monocotyledonous and dicotyledonous plants that are grown or occur in corn production areas. Expansion of the host range should involve surveys of plants growing within corn fields and occurring in pastures, ditches or conservation reserve area acres near corn fields for bacterial leaf streak symptoms and also for asymptomatic endophytic populations of the pathogen. Grain sorghum was shown to be readily infected by $X$. vasicola $\mathrm{pv}$. vasculorum when inoculated under controlled conditions in this and previous studies (Lang et al. 2017), but the pathogen has not been found causing disease in grain sorghum in Nebraska or Kansas, even in grain sorghum fields adjacent to corn fields with bacterial leaf streak (T. Jackson-Ziems, unpublished data; D. Jardine, Kansas State University, personal communication). While this might indicate that $X$. vasicola pv. vasculorum does not readily cause symptom development in grain sorghum under field conditions, the alternative explanation that the bacterium establishes endophytic populations in the field on asymptomatic grain sorghum needs to be explored.

Despite the need for further research on the role of alternative hosts in the bacterial leaf streak disease cycle, the results from this study have multiple implications for the management of the disease in corn. The native and non-native grasses newly discovered to be hosts for $X$. vasicola pv. vasculorum, are perennial, with the exception of rice and oat. If these perennial grasses become symptomatically or asymptomatically infected with this bacterium, there is the possibility that the pathogen can persist in the infected plants season after season. These grasses are commonly found in pastures, which can be baled for hay and transported to other areas or states for use as livestock feed. Transportation of hay bales containing infected grasses could potentially be a mechanism of pathogen spread to new locations. Prevention of pathogen spread via this route might require pastures in proximity to corn fields with bacterial leaf streak be monitored for the pathogen prior to the grasses being baled. The finding that a number of monocot weeds can serve as hosts for $X$. vasicola pv. vasculorum suggests that weed management, as well as crop rotation and tillage, may be needed to minimize overwinter survival of the bacterium. Furthermore, demonstration that grain sorghum, rice, and oat can become infected with $X$. vasicola pv. vasculorum suggests that these crops should not be grown in rotation with corn in fields infested with the pathogen.

\section{ACKNOWLEDGMENTS}

We thank Jillian Lang for her helpful suggestions on this research; Kent Eskridge for his review of earlier drafts of this paper; Steve Knox, P. Stephen Baenziger, Ismail Dweikat, and Yeshi Wamishe for providing crop seed; Matt Sousek and Keenan Amundsen for providing turf and ornamental grass seed; Rich Russell, Arrow Seed Company, for native grass seed; Amit Jhala and Kasey Schroeder for weed seed; and Michayla Goedeken and Jen Foster for technical assistance.

\section{LITERATURE CITED}

Araujo, W. L., Marcon, J., Maccheroni, W., Jr., Van Elsas, J. D., Van Vuurde, J. W., and Azevedo, J. L. 2002. Diversity of endophytic bacterial populations and their interaction with Xylella fastidiosa in citrus plants. Appl. Environ. Microbiol. 68:4906-4914.
Bowman, N. D., and Bissonnette, S. 2016. New bacterial leaf disease "bacterial leaf streak" identified in one northern Illinois county. The Bulletin, University of Illinois Extension.

Burch, G., and Sarathchandra, U. 2006. Activities and survival of endophytic bacteria in white clover (Trifolium repens L.). Can. J. Microbiol. 52: 848-856.

Damicone, J., Cevallos, F., and Olson, J. 2018. First report of bacterial leaf streak of corn caused by Xanthomonas vasicola pv. vasculorum in Oklahoma. Plant Dis. 102:437.

Dawson, J. H., and Bruns, V. F. 1962. Emergence of barnyardgrass, green foxtail, and yellow foxtail seedlings from various soil depths. Weeds. 10: 136-139.

Dyer, R. A. 1949. Botanical surveys and control of plant diseases. Farming in South Africa. Annu. Rep. Dep. Agric. S. Afr. 275:119-121.

Hartman, T., Harbour, J., Tharnish, B., Van Meter, J., and Jackson-Ziems, T. A. 2017b. Epidemiology and distribution of bacterial leaf streak of corn caused by Xanthomonas vasicola. Phytopathology 107:S5.160.

Hartman, T., Tharnish, B., Harbour, J., and Jackson-Ziems, T. A. 2017a. Alternative hosts of Xanthomonas vasicola causing bacterial leaf streak of corn. Phytopathology 107:S5.170-171.

Hartman, T., Tharnish, B., Harbour, J., and Jackson-Ziems, T. A. 2018. Alternative hosts of Xanthomonas vasicola pv. vasculorum causing bacterial leaf streak of corn. Phytopathology 108:S2.28.

Hartman, T. M. 2018. Investigation of alternative hosts and agronomic factors affecting Xanthomonas vasicola pv. vasculorum, causal agent of bacterial leaf streak of corn. MS thesis, University of Nebraska.

Korus, K., Lang, J. M., Adesemoye, A. O., Block, C. C., Pal, N., Leach, J. E., and Jackson-Ziems, T. A. 2017. First report of Xanthomonas vasicola causing bacterial leaf streak on corn in the United States. Plant Dis. 101: 1030.

Lang, J. M., DuCharme, E., Ibarra Caballero, J., Luna, E., Hartman, T., Ortiz-Castro, M., Korus, K., Rascoe, J., Jackson-Ziems, T. A., Broders, K., and Leach, J. E. 2017. Detection and characterization of Xanthomonas vasicola pv. vasculorum (Cobb 1894) comb. nov. causing bacterial leaf streak of corn in the United States. Phytopathology 107:1312-1321.

Leite, R. P., Custódio, A. A. P., Madalosso, T., Rodrigues Robaina, R. R., Duin, I. M., and Sugahara, V. H. 2018. First report of the occurrence of bacterial leaf streak of corn caused by Xanthomonas vasicola pv. vasculorum in Brazil. Plant Dis. 103:145.

Newman, P. R., and Moser, L. E. 1907. Grass seedling emergence, morphology, and establishment as affected by planting depth. Agron. J. 80:383-387.

North, D. S. 1935. The gumming disease of sugarcane, its dissemination and control. Agric. Rep. Colon. Sug. Refg. Co. 10(tech):149.

Plazas, M. C., De Rossi, R. L., Brücher, E., Guerra, F. A., Vilaró, M., Guerra, G. D., Wu, G., Ortiz-Castro, M. C., and Broders, K. 2018. First report of Xanthomonas vasicola pv. vasculorum causing bacteria leaf streak of maize (Zea mays) in Argentina. Plant Dis. 102:1026.

Ricaud, C., and Autrey, L. J. C. 1989. Gumming disease. Pages 21-38 in: Diseases of Sugarcane: Major Diseases. C. Ricaud, B. T. Egan, A. G. Gillaspie Jr., and C. G. Hugues, eds. Elsevier, Amsterdam, Netherlands.

Robertson, A. 2016. Bacterial leaf streak confirmed in Iowa. ICM News. Iowa State University Extension and Outreach.

Schulz, B., Wanke, U., Draeger, S., and Aust, H. J. 1993. Endophytes from herbaceous plants and shrubs: effectiveness of surface sterilization methods. Mycol. Res. 97:1447-1450.

Stubbendieck, J., Friisoe, G. Y., and Bolick, M. R. 1994. Weeds of Nebraska and the Great Plains. Nebraska Department of Agriculture, Lincoln, NE.

Velázquez, E., Rojas, M., Lorite, M. J., Rivas, R., Zurdo-Piñeiro, J. L., Heydrich, M., and Bedmar, E. J. 2008. Genetic diversity of endophytic bacteria which could be found in the apoplastic sap of the medullary parenchyma of the stem of healthy sugarcane plants. J. Basic Microbiol. 48: 118-124.

Vidaver, A. K. 1967. Synthetic and complex media for rapid detection of fluorescence of phytopathogenic pseudomonads: Effect of the carbon source. Appl. Microbiol. 15:1523-1524.

Vidaver, A. K., and Lambrecht, P. A. 2004. Bacteria as plant pathogens. The Plant Health Instructor. doi:10.1094/PHI-1-2004-0809-01.

Weaver, J. E., and Bruner, W. E. 1948. Prairies and pastures of the dissected loess plains of Central Nebraska. Ecol. Monogr. 18:507-549. 